\title{
Differences in Students' Spatial Ability and Self-Regulated Learning Who are Given Guided Discovery Learning Model Based on Malay Deli Culture with Cooperative Learning
}

\author{
Widia Shopa * Bornok Sinaga Edi Syahputra \\ University of Medan, Jl. Willem Iskandar Psr. V Medan, Indonesia
}

\begin{abstract}
This study aims toknow: (1) The differences in students' spatial ability and self-regulated learning who are given guided discovery learning model based on Malay Deli culture and cooperative learning, (2) Interaction between learning models with gender in increasing students' spatial ability and students' self-regulated learning. This type of research is quasi-experimental. This research was conducted at SMP N 28 Medan. The population in this study were all students of class VIII. Based on the results of the analysis, the results of the study are: (1) Improvement of spatial ability and self-regulated learning of students who are given guided discovery learning model based on Malay Deli culture is higher than students who are given cooperative learning, (2) There is an interaction between learning models with gender in increasing students' spatial ability and self-regulated learning.
\end{abstract}

Keywords: Spatial Ability, Self-regulated Learning, Guided Discovery Learning Model Based on Malay Deli Culture, Cooperative Learning

DOI: $10.7176 / \mathrm{JEP} / 10-27-11$

Publication date:September $30^{\text {th }} 2019$

\section{PRELIMINARY}

The mathematical context especially geometry occupies a special position in the curriculum. From a psychological point of view, geometry is the presentation of abstractions from visual and spatial experiences, for example plane, patterns, measurements and mapping. Whereas from a mathematical point of view, geometry provides approaches to problem solving, for example drawings, diagrams, coordinate systems, vectors, and transformations. Geometry not only develops cognitive abilities of students but also helps in the formation of memory, namely concrete objects that become abstract (Asis, Arsyad and Alimuddin, 2015: 79).

Kariadinata (2010) stated that "There are many geographic problems that require visualization in problem solving and in general students find it difficult to construct geometrical spaces". Therefore to master the geometry of the plane and geometry of space, students must have spatial ability.

Turgut and Yilmaz (2012) said that there is a positive relationship between spatial ability and academic success. Students who have high spatial ability have higher mathematical achievements compared to students who have moderate and low spatial ability (Faradhila, Sujadi, and Kuswardi, 2013).

The results of teacher observations and interviews at SMP Negeri 28 Medan, found that students mathematical ability are quite varied, ranging from high, medium, and low. Through tests that were tested on students only $10 \%$ of students showing performance of their spatial ability, this was also found by (Princess, Hasratuddin and Syahputra , 2019) that based on the students' worksheets on tests of mathematical spatial ability, the researchers found that students had difficulty in visualizing the objects. The low ability of students due to spatial ability itself requires the ability to think at a high level in observing the spatial world and imagining geometric forms because it requires high imagination (Asis, Arsyad, and Alimuddin, 2015).

To achieve the maximum spatial ability of students there needs to be practice and in line with students' soft skills. One important factor in supporting this is self-regulated learning. Learning progress will be formed from the process of self-regulated learning. Self-regulated learning is one indicator that determines the success of student learning (Sumarmo and Sugandi, 2010). Each individual student will also have different ways of approaching the learning situation, in the way they receive, organize, and relate their experiences in the way they respond to a problem. One of the characteristics of students who focus on individual differences and individual assessments is gender issues. Gender role behavior is behavior that is widely learned in learning (Slavin, 2011).

Supporting learning models are guided discovery and cooperative. Application of cooperative learning and guided discovery learning is a concept that helps teachers link between the material taught by social situations, the real world and encourages students to make connections between the knowledge they have and their application in their lives as family members and the community.

The learning model guided discovery learning allows students to use all of their knowledge (cognitive, affective and pshycomotor), especially the process of learning to find concepts or principles by themselves and train their mental processes that are characteristic of a scientist (Pedaste et al., 2015).

While the cooperative learning model is a students' learning activity carried out in groups. "The group 
learning model is a series of learning activities carried out by students in certain groups to achieve the learning objectives that have been formulated" (Sanjaya , 2008).

Education is part of culture, education and culture have mutual influence. If culture changes maybe education will also change (Siregar et al., 2018). Cultural context can be used as a tool for learning to motivate students to apply mathematical concepts, work in groups, and perceived relationships between various subjects (Saragih et al., 2016). Thus it is possible to have a local cultural context, namely Malay Deli culture in mathematics learning, meaningful learning processes will occur as expected. So education and culture are one of the most important and unavoidable units in everyday life.

This will give birth to a competent and dignified generation, reflect cultural values, participate in shaping the nation's character, contribute to the creation of national identity, and contribute to preserving the nation's culture (Siregar, 2018). Based on this reason, a study was conducted to review differences in spatial ability and self-regulated learning of students who were given a guided discovery learning model based on Malay Deli culture and cooperative learning.

\section{LITERATURE REVIEW}

\section{Spatial Ability}

Maier (1998) suggested that "spatial ability is a skill possessed by humans that is relevant to a high level in our lives. Spatial ability consists of five elements, namely: (1) Spatial Perception, namely the ability to observe the location of objects. (2) Visualization is the ability to show changes or movements of building elements, (3) Mental Rotation is the ability to rotate objects (4) Spatial Relations, namely the ability to understand the composition of an object and its parts and their relationships with each other. (5) Spatial Orientation is the ability to observe an object from a different perspective. In line with that Tambunan (2006) argued that "spatial ability is an abstract concept that includes spatial perception involving spatial relationships including orientation to complicated abilities that involve manipulation and mental rotation". In other words, spatial ability is the ability to capture and distinguish stimuli about space obtained through visual imagery in the head without the use of concrete objects. The key to spatial thinking is a constructive mix of three elements: the concept of space, a tool of representation, and the process of reasoning (NRC, 2010).

\section{Self-regulated Learning}

Self Regulated Learning (SRL) is an active and determined process in which students determine learning goals and monitor, regulate, control their cognition, motivation, and attitudes, be guided and limited by their goals, and features of contextual environments (Abubakar and Mohammad 2015, Pintrich, 1990, Rusman, 2014). Selfregulated in learning is a necessity and demand in education today. In addition there are three phases in the cycle of students' self-regulated learning according to Zimmerman, (1989: 178) is "Forethought Phase, Performance Phase and (Self-reflection Phase". Thus the importance of students learning independently is to be able to use various sources and media for learning without relying on help from others and not to rely on learning only from the teacher, because the teacher acts as a facilitator and consultant is not the only source of knowledge.

\section{Guided Discovery}

Guided discovery learning model in terms of the definition of discovery is a process of knowledge where students can assimilate concepts or principles (Wartono, Hudha, and Batlolona, 2017). The knowledge process is observing, categorizing, making hypotheses, explaining, measuring, drawing conclusions and so on (Alfieri et al., 2011). According to Makoolati et al., (2015) discovery learning provides opportunities for student-centered activities and allows students to learn from not only the teacher as the only source of learning.

The learning steps using the guided discovery model are: (1) Introduction, (2) Open-ended phase, (3) Convergent, (4) Closing and Application (Eggen and Don Kauchak, 2012). Through guided discovery learning models will increase student activity which is greater, because it is process oriented, to find out for themselves the information needed to achieve instructional goals. Thus the discovery method is oriented to the process and results together.

\section{Cooperative}

Cooperative learning is a learning model that focuses on using small groups of students to work together in maximizing learning conditions to achieve learning goals (Sugiyanto, 2010). But the cooperative learning model is not the same as learning in groups (Anita Lie, 2007). Cooperative learning is a learning model that emphasizes positive interdependence among individual students, individual responsibility, face-to-face, intensive communication between students, and evaluation of group processes (Arif, 2009). Cooperative learning according to Slavin (2005: 4-8) refers to a variety of learning models in which students work together in small groups consisting of different levels of achievement, gender, and ethnic background to help one another. in studying subject matter. In cooperative classes, students are expected to be able to help each other, discuss each other, and argue to hone the knowledge they have mastered at the time and close the gap in their understanding. Cooperative learning is more than just group learning because in this learning model there must be a structure of encouragement and tasks that are cooperative so as to allow open interaction and effective interdependent 
relationships between group members.

The steps of cooperative learning model are: (1) Conveying objectives and motivating students, (2) Presenting information, organizing students into groups learning, (3) Guiding group of work and Study groups, (4) Evaluation, (5) Providing Views (Rusman , 2012). In a cooperative learning system, students learn to work together with other members. In this model students have two responsibilities, namely they learn for themselves and help fellow group members to learn. Students learn together in a small group and they can do it alone.

\section{METHOD}

This type of research is quasi-experimental research. This research was conducted at SMP N 28 Medan in the second semester of the 2018/2019 academic year. In this study, sample selection was carried out using cluster random sampling technique. In this sampling, the population is divided into several. Clusters needed are randomly taken by randomization process. Every member in the group drawn randomly is the required sample (Amadil, Glory, and Kufre Akpan, 2017) .

Based on random sampling from nine classes VIII in SMP 28 Medan, a sample of 2 classes was chosen, namely class VIII-2 as the experimental class I with a guided discovery learning model based on Malay Deli culture and class VIII-3 as the experimental class II given learning with cooperative model. Each number of students in the two classes is 32 students. The design of this research analysis is a $2 \times 2$ factorial design using twoway analysis of variance (ANOVA) .

Indicators of students' spatial ability tests consist of 5 aspects: Spatial perception, spatial visualization, mental rotation, spatial relations, spatial orientation. Indicators of self-regulated learning are organized into three aspects, namely: Planning, business control in academic classes and cognitive strategies for understanding material.

Data collection technique was obtained through students' mathematical spatial ability tests and SRL questionnaires. The instrument has been validated and meets the requirements for testing validity and reliability. Data collection will be carried out in two stages, collecting data about students' self-regulated learning and collecting data about students' mathematical spatial ability.

\begin{tabular}{l|c|c}
\multicolumn{3}{c}{ Table 1. Research design } \\
\hline \multicolumn{1}{c|}{ Class } & Treatment & Posttest \\
\hline Experimental I & $\mathrm{X}_{1}$ & $\mathrm{~T}_{1}$ \\
\hline Experimental II & $\mathrm{X}_{2}$ & $\mathrm{~T}_{1}$ \\
\hline
\end{tabular}

\section{Explanation:}

$\mathrm{X}_{1}$ : Treatment using guided discovery based Malay Deli culture learning model (6 meetings @990 minutes)

$\mathrm{X}_{2}$ : Treatment using cooperative learning model (6 meetings @90 minutes)

$\mathrm{T}_{1}$ : Post test

Based on the research design, the linear equation of the experiment adapted from Syahputra (2016) is as follows:

$$
Y_{i j k}=\mu+\alpha_{i}+\beta_{j}+(\alpha \beta)_{i j}+\varepsilon_{k(i j)}
$$

The research hypothesis is as follows:

Hypothesis 1: To test differences in students' spatial ability

Hypothesis 2: To test differences in students' self regulated learning

Hypothesis 3: To examine the interaction between learning models and gender on students' spatial ability

Hypothesis 4: To examine the interaction between learning models and gender on students' self-regulated learning

\section{RESULTS}

\section{Spatial Analysis Results}

Before the data were analyzed, the normality of the data were tested using the Kolgomorov test and the homogeneity test used the Levene test as a requirement for qualitative analysis. The results obtained that the two classes come from populations that are normally distributed and homogeneous. Data on the spatial ability of students in the class who were given a guided discovery learning model based on Malay Deli culture and cooperative learning models are shown in Table 2.

Table 2 . Spatial Ability Test Results

\begin{tabular}{|c|c|c|c|c|}
\hline Class & Gender & $\mathrm{N}$ & Average & $\bar{x}$ \\
\hline \multirow{2}{*}{ Experimental I } & Male & 15 & 78.22 & \multirow{2}{*}{75.10} \\
\hline & Female & 17 & 72.35 & \\
\hline \multirow{2}{*}{ Experimental II } & Male & 19 & 56.14 & \multirow{2}{*}{62.19} \\
\hline & Female & 13 & 71.03 & \\
\hline
\end{tabular}

Based on Table 2 it can be seen that male students in the experimental class I numbered 15 people with an average score of 78.22 and female students amounted to 17 people with an average value of 72.35 . This shows 
that the spatial ability of male students is higher than that of female students for the experimental class I. While male students in experimental class II numbered 19 people with an average value of 56.14 and female students amounted to 13 people with an average value of 71.03 . Thus it can be stated that the spatial ability of male students is lower than that of female students for experimental class II.

After that, analyzed using analysis of variance (ANOVA) to test 4 hypotheses proposed in the study with a two-way analysis of variance tests. The results of data analysis can be seen in the following Table 3:

Table 3. Anava Analysis Results on Student Spatial Ability

\begin{tabular}{|c|c|c|c|c|c|}
\hline \multicolumn{6}{|c|}{ Tests of Between-Subjects Effects } \\
\hline \multicolumn{6}{|c|}{ Dependent Variable: Spatial_Ability } \\
\hline Source & Type III Sum of Squares & Df & Mean Square & $\mathrm{F}$ & Sig. \\
\hline Corrected Model & $4665.800^{\mathrm{a}}$ & 3 & 1555.267 & 5.353 & .002 \\
\hline Intercept & 302446.655 & 1 & 302446.655 & 1040.956 & .000 \\
\hline Learning_Model & 2163.657 & 1 & 2163.657 & 7.447 & .008 \\
\hline Gender & 321.015 & 1 & 321.015 & 1.105 & .297 \\
\hline Learning_Model $*$ Gender & 1681.088 & 1 & 1681.088 & 5.786 & .019 \\
\hline Error & 17432.825 & 60 & 290.547 & & \\
\hline Total & 323680.823 & 64 & & & \\
\hline Corrected Total & 22098.625 & 63 & & & \\
\hline
\end{tabular}

a. $\mathrm{R}$ Squared $=.211($ Adjusted R Squared $=.172)$

From the results of the analysis of the two variants above, can explain the following:

1) Based on Table 3, it shows that the significance value for the model is 0.008 (sig. $<0.05$ ), there are differences in the spatial ability of learning through guided discovery learning model with cooperative learning model.

2) Then from Table 3, it also appears that the significance for the Learning_Model * Gender line is 0.019 (sig. $<0.05$ ), thus rejecting $\mathrm{H}_{0}$ and accepting $\mathrm{H}_{\mathrm{a}}$. So it can be concluded that there is an interaction between learning models and gender with students' spatial ability. This result can also be explained through Figure 1 below:

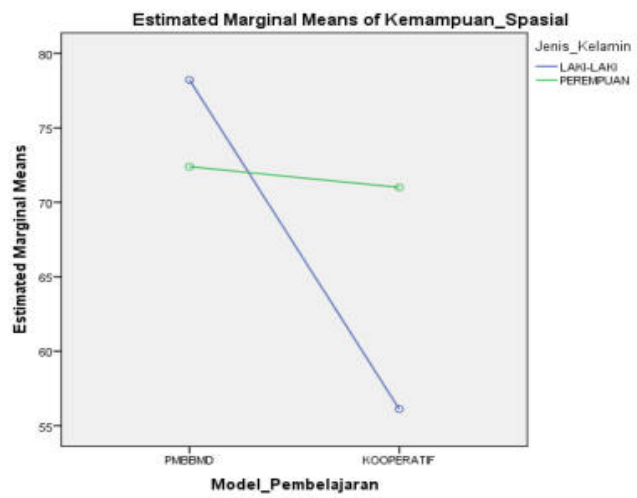

Figure 1 . Interaction between Learning Model and Gender Against Spatial Ability

Results of Analysis of Student Learning Independence

Data on the self-regulated learning of students in classes that are given guided discovery learning model based on Malay Deli culture and classes that are given cooperative learning models are shown in the following Table 4 :

Table 4 . Student Self-Regulated Learning Test Results

\begin{tabular}{|c|c|c|c|c|}
\hline Class & Gender & $\mathrm{N}$ & Average & $\bar{x}$ \\
\hline \multirow{2}{*}{ Experimental I } & Male & 15 & 76.39 & \multirow{2}{*}{75.10} \\
\hline & Female & 17 & 85.38 & \\
\hline \multirow{2}{*}{ Experimental II } & Male & 19 & 69.00 & \multirow{2}{*}{62.19} \\
\hline & Female & 13 & 67.00 & \\
\hline
\end{tabular}

Based on Table 4 it can be seen that male students in the experimental class I numbered 15 people with an average score of 76.39 and female students amounted to 17 people with an average score of 85.38. This shows that the self-regulated learning of male students after being given lower treatment compared with female students for experimental class I. While male students in experimental class II numbered 19 people with an average score of 69 and female students amounted to 13 people with an average value of 67 . Thus it can be stated that the self- 
regulated learning of male students after being given higher treatment compared with female students for experimental class II.

Table 5. Anava Analysis Results on Students' Self-regulated Learning

Tests of Between-Subjects Effects

\begin{tabular}{l|l|l|l|l|l}
\multicolumn{7}{c}{ Dependent Variable: Self Regulated Learning } \\
\hline Source & Type III Sum of Squares & df & Mean Square & F & Sig. \\
\hline Corrected Model & $3315.830^{\mathrm{a}}$ & 3 & 1105.277 & 15.321 & .000 \\
\hline Intercept & 347332.617 & 1 & 347332.617 & 4814.628 & .000 \\
\hline Learning_Model & 2534.070 & 1 & 2534.070 & 35.127 & .000 \\
\hline Gender & 192.185 & 1 & 192.185 & 2.664 & .108 \\
\hline Learning_Model * Gender & 492.859 & 1 & 492.859 & 6.832 & .011 \\
\hline Error & 4328.466 & 60 & 72.141 & & \\
\hline Total & 364284.672 & 64 & & & \\
\hline Corrected Total & 7644.296 & 63 & & & \\
\hline
\end{tabular}

a. R Squared $=.434$ (Adjusted R Squared $=.405$ )

From the results of the analysis of the two variants above, can explain the following:

1) Based on Table 5, it shows that the significance value for the model of $0,000(\mathrm{sig} .<0.05)$, then there are differences in student self-regulated learning through the guided discovery learning model with cooperative learning model.

2) Then from Table 5, it also appears that the significance for the Model_Learning * Gender line is 0.011 (sig. $<0.05$ ), thus rejecting Ho and accepting Ha. So it can be concluded that there is an interaction between learning models and gender with student self-regulated learning. This result can also be explained through Figure 2 below:

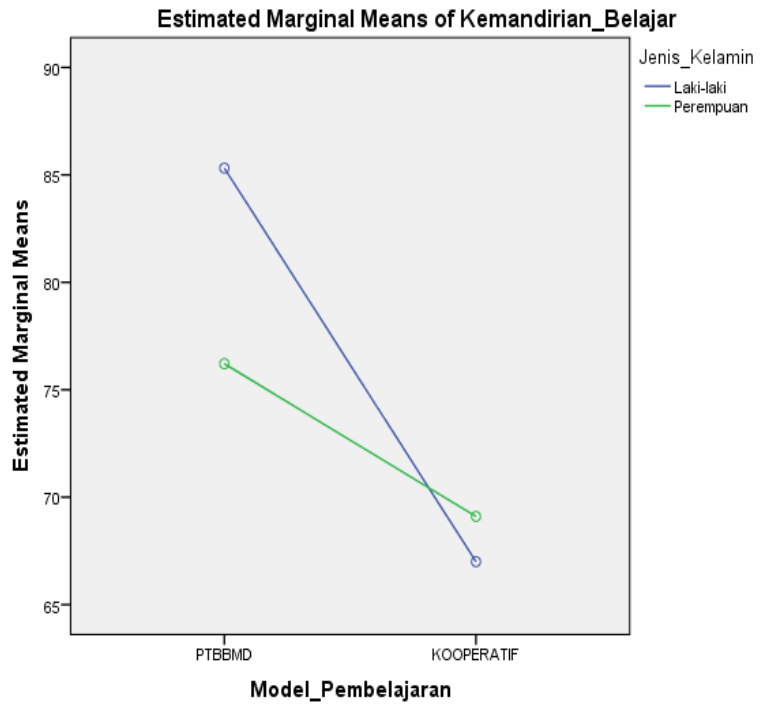

Figure 2 . The Interaction Between Learning Models and Gender of Students' Self-regulated Learning

\section{DISCUSSION}

Based on the average value, and hypothesis testing showed that the ability of spatial students with learning model guided discovery based on culture Malay Deli better than cooperative learning model. The results of this study have similarities found in previous studies Fajri, Johar and Ikhsan (2016) show that the spatial ability of students who are taught with guided discovery models is good to be applied in learning in schools. The Malay Deli based culture-guided guided learning model provides opportunities for students to develop mathematical learning concepts derived from studying the surrounding environment, especially local culture. In addition to providing cultural values contained in local culture, students will also learn in real contexts where students can develop optimally and at the same time the creative activities of each student are communicated through the teaching-learning process. The teacher packages the learning while taking advantage of the opportunity to develop further learning material that is more or less known by the students themselves. In this way students will truly feel interested and highly motivated to solve their own problems.

Based on the average value and testing the hypothesis shows that the self-regulated learning of student with the guided discovery learning model based on Malay Deli culture is better than the cooperative learning model. 
Students have control over the learning process through knowledge and build understanding, reinforcement in decision making and learning motivation. It is influenced that the guided discovery learning model is more able to emphasize direct learning experiences through inquiry activities, discover concepts and then apply concepts that have been obtained in daily life so that students are more independent in their learning. Based on hypothesis testing there is an interaction between learning models and gender on students' spatial ability. There are several things in this study that cause interaction between the learning model (guided discovery learning model with Malay Deli culture frame and cooperative learning model) with gender on students' spatial ability this is caused by (1) grouping of initial mathematical abilities, student researchers are only guided by acquisition of student scores on the initial mathematical ability test taken from the national exam (UN) questions that do not reflect the students' spatial ability expected from students (2) gender differences do not play a role in students' spatial ability, in the sense that it cannot be concluded clearly whether men or women are better at learning mathematics (3) The guided discovery learning model based on Malay Deli culture and cooperatively together significantly influences students' spatial ability.

Based on hypothesis testing, there is an interaction between learning models and gender on student selfregulated learning. There are several things in this study that cause interaction between the learning model (the guided discovery learning model based on Malay Deli culture and cooperative learning models) with gender on the self-regulated learning this is caused by (1) gender differences do not play a role in the students' selfregulated learning, in the meaning cannot be concluded clearly whether male or female is better in learning mathematics. 2) The guided discovery learning model based on Malay Deli culture and cooperative learning together significantly influence students' self-regulated learning.

\section{CONCLUSION}

Based on the results of the analysis and discussion in this study, it can be concluded that

1) The spatial ability and self-regulated learning of student taught through the Malay Deli -based guided discovery model is higher than the spatial ability of students taught through cooperative learning model where the spatial ability of students is influenced by learning models and gender, with a percentage of the influence of the learning model of $19.76 \%$ and the effect of gender by $25.66 \%$. There seems to be a positive correlation between spatial ability and the guided discovery model based on Malay Deli culture.

2) There is an interaction between learning models with gender on students' spatial ability and selfregulated learning. Where the spatial ability of students is influenced by learning models and gender, with a percentage of the influence of the learning model of $10.84 \%$ and the influence of the sex of $27.29 \%$. There seems to be a positive correlation between students' self-regulated learning and the guided discovery model based on Malay Deli culture.

3) There is an interaction between learning (guided discovery learning model based on Malay Deli culture and cooperative learning model) in terms of gender (male and female) on students' spatial ability. Where the percentage of interaction between learning models and gender amounted to $3.79 \%$.

4) There is an interaction between learning (a guided discovery learning model based on Malay Deli culture and cooperative learning models) in terms of gender (male and female) on the students' selfregulated learning. Where the percentage of interaction between learning models and gender on learning independence of $2,80 \%$.

\section{Disclosure statement}

No potential conflict of interest was reported by the authors.

\section{Notes on contributors}

Widia Shopa - State University of Medan, Medan, Indonesia.

Bornok Sinaga - State University of Medan, Medan, Indonesia.

Edi Syahputra - State University of Medan, Medan, Indonesia.

\section{BIBLIOGRAPHY}

Abubakar, B.A., \& Mohammad Y.A., 2015. "Self-Directed Learning and Abilitys of Problem Based Learning: A Case of Nigerian Secondary Schools Chemistry Students," International Education Studies, 8 (12). 70-78. 2015.

Alfieri, L., Brooks, P. J., Aldrich, N. J., \& Tenenbaum, H. R. 2011. Does discovery-based instruction enhance learning? Journal of Educational Psychology, 103(1), 1-18.

Amadil, Glory, Kufre Akpan. 2017 Influence of Student-Teacher Communication on Students' Academic Achievement for Effective Teaching and Learning. American Journal of Educational Research, 2017, Vol. 5, No. 10, 1102-1107 
Anita Lie. 2007. Kooperatif Learning (Mempraktikkan Cooperative Learning di Ruang-ruang Kelas). Jakarta: Grasindo.

Arif Rohman. 2009. Memahami Pendidikan dan Ilmu Pendidikan. Yogyakarta: LaksBang Mediatama.

Asis, M., Arsyad, N \& Alimuddin. 2015. Profil Kemampuan Spasial Dalam Menyelesaikan Masalah Geometri Siswa Yang Memiliki Kecerdasan Logis Matematis Tinggi Ditinjau Dari Perbedaan Gender. Jurnal Daya Matematis, Vol.3 No.1, 78-87

Eggen, Paul dan Don Kauchak. (2012). Strategies and Models for Teachers Teaching Content and Thinking Skill. Boston: Pearson Education, Inc., Publishing.

Fajri, Johar \& Ikhsan. 2016. Peningkatan kemampuan Spasial dan Self Efficay Siswa Melalui Model Discovery Learning Berbasis Multimedia. Beta Jurnal Tadris Matematika. Vol. 9 No. 2 (Nopember) 2016, Hal.180196

Faradhila, N., Sujadi, I., \& Kuswardi, Y. 2013. Eksperimentasi Model Pembelajaran Missouri Mathematics Project (MMP) pada Materi Pokok Luas Permukaan serta Volume Prisma dan Limas Ditinjau dari Kemampuan Spasial Siswa Kelas VIII Semester Genap SMP Negeri 2 Kartasura. Jurnal Pendidikan Matematika Solusi, 1 (1), 67 - 74.

Kariadinata, R. 2010. "Kemampuan Visualisasi Geometri Spasial Siswa Madrasah Aliyah Negeri (Man) Kelas X Melalui Software Pembelajaran Mandiri”. Jurnal EDUMAT. 1(2)

Maier, P. H. 1998. Spatial geometry and spatial abilities How to make solid geometry solid? Selected Papers from the Annual Conference of Didactics of Mathematics 1996.

Makoolati, N., Amini, M., Raisi, H., Yazdani, Sh., \& Razeghi, A. V. 2015. The effectiveness of Guided Discovery Learning on the learning and satisfaction of nursing students, Hormozgan Medical Journal, 18(6), 490-496.

NRC. 2010 Learning to think Spatially. Washington DC: The National Academies Press.

Pedaste, M., Maeots, M., Siiman, L. A., Jong T, d., van Riesen, S. A. N., Kamp, E. T., Manoli, C. C., Zacharia, Z. C., \& Tsourlidaki, E. (2015). Phases of inquiry-based learning: Definitions and the inquiry cycle. Educational Research Review, 14, 47-61.

Pintrich. 1990. Motivasi dan Self-Regulated Learning Component of Classroom Academic Performance. Jurnal Psikologi Pendidikan, 82 (1). 33-40.

Putri, KP., Hasratuddin dan syahputra , E, 2019. Development Of Learning Devices Based On Realistic Mathematics Education To Improve Students' Spatial Ability And Motivation. International Electronic Journal Of Mathematics Education. Vol. 14, No. 2, 393-400

Rusman 2014. Model Pembelajaran: Mengembangkan Guru Profesional. Jakarta: Rajawali Pers

Sanjaya, Wina. 2008. Strategi Pembelajaran: Berorientasi Standar Proses Pendidikan. Jakarta: Kencana Prenada Media Group

Saragih, S., E. Napitupulu, E. E. \& Fauzi, A. 2016. Developing Learning Model Based on Local Culture and Instrument for Mathematical Higher Order Thinking Ability. International Education Studies; Vol. 10, No. 6; 2017. Published by Canadian Center of Science and Education

Siregar, AS., Surya, E., Syahputra E, dan Sirait, AR, 2018. The Improving Mathematical Communication Ability and Students' Self-Regulation Learning through Realistic Mathematical Approach Based on Batak Toba Culture. American Journal of Educational Research, 2018, Vol. 6, No. 10, 1397-1402

Slavin, Robert E. 2005. Cooperative Learning: theory, research and practice. Terjemahan dalam Bahasa Indonesia (Penerjemah : N. Yusron). London: Allymand Bacon.

Slavin, Robert E. 2011. Psikologi Pendidikan, Teori dan Praktik. Edisi Kesembilan. Terjemahan dalam Bahasa Indonesia (Penerjemah : Marianto Samosir). Jakarta : PT. Indeks.

Sumarmo, U. \& Sugandi, AS 2010. Pengaruh Pembelajaran Berbasis Masalah dengan Setting Kooperatif Jigsaw Terhadap Kemajuan Komunikasi Matematis Serta Kemandirian Belajar Siswa SMA. Prosiding Seminar Nasional Matematika dan Pendidikan Matematika. 27 November 2010

Syahputra, Edi. 2016. Statistika Terapan Untuk Quasi Dan Pure Experiment. Medan: ISBN 978-602-0888-82-8. Unimed Press

Tambunan, Siti M. 2006. Hubungan Antara Kemampuan Spasial dengan Prestasi Belajar Matematika. Makara, Sosial Humaniora.

Turgut, M. \& Yilmaz, S. 2012. Relationship among Preservice Primary Mathematics Teachers' Gender, Academic Success, and Spatial Ability. International Journal of Instruction, 5 (2), 5 - 20.

Wartono, W., Hudha, M,N dan Batlolona, J,R. 2017. How Are The Physics Critical Thinking Skills of The Students Taught by Using Inquiry-Discovery Through Empirical and Theorethical Overview?. EURASIA Journal of Mathematics, Science and Technology Education. 2018 14(2):691-697 